田中利男、西村有平、角田宏、中充子

三重大学医学部薬理学教室

\title{
PHARMACOGENOMICS AND DRUG DISCOVERY
}

Toshio TANAKA, Yuhei NISHIMU RA, Hiroshi TSU NODA, Mich iko NAKA

Department of Molecular and Cellular Pharmacology

Mie University School of Medicine

Tsu 514-8507

薬理ゲノミクス（pharmacogenomics, 薬理ゲノム科学) は、ゲノム科学 (genomics)を基盤にして、疾患感受性、

薬物応答性、薬物の副作用をゲノムレベ ルで解析し、創薬を目指す新しい薬理学 である。その結果、より安全で有效性の 高い医薬品の開発、各個人に適した薬物 の投与（テーラーメード医療）が可能に なる事が期待されている。さらに、有効 な患者集団の予測、副作用の回避、既存 薬の新規適応症の発見など臨床開発の効 率化も、期待されている。ここでは、主 に前臨床ゲノム創薬に焦点をあて、新規 創薬ターゲット探索とターゲットバリデ ーションにおける薬理ゲノミクスの役割 について、我々の最近の研究成果を基礎 に解説を試みる。

\section{1. 創薬における薬理ゲノミクス}

創薬は、数多くの課題を克服して初めて 達成される総合的テクノロジーであるが、 特に前臨床の課題で最大のものは適切な 新規創薬ターゲットの決定である。しか しながらこの課題には、すでに多くの困 難が内在している。たとえば、(1) その 薬物標的分子に作用する医薬品により、 確実に病態を改善することが予測あるい は期待できる根拠を示す必要がある ( target validation)。(2) 創薬の前臨 床研究の多くは、ヒトではなく実験動物 を使用するが、その薬物標的分子におい て種差の問題を超えた有効性を確保する 必要がある( species bridge )。(3) そ の薬物標的分子を介した重大な臨床上の

\section{Genome}

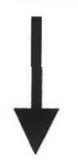

Transcriptome

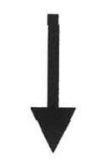

Proteome
Gene Variation(SNPs)

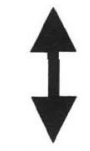

Gene Expression

Gene Function

図1.創薬における薬理ゲノミクス研究戦略。 
副作用が無いことを、保証する必要があ る(toxicogenomics)。

すなわち、これらの条件を充たす新規創 薬ターゲットをヒトゲノムプロジェクト により明らかにされつつある約 10 万種 類といわれる発現遺伝子から抽出する必 要がある。そこで、ゲノムスケールの創 薬夕一ゲッ卜探索研究が不可欠になる。 言うまでもなく、セントラルドグマに従 い遺伝子は m RNA に転写され、最終的 には蛋白質に翻訳されるが、これらをゲ ノムスケールで包括的に考えるとゲノム (genome)からトランスクリプトーム (transcriptome)、さらにプロテオーム (proteome)における解析が必要となる

(図 1)。すなわち、ゲノム解析では主 に一塩基多型(SNPs)などの遺伝子変異 (gene variation)、トランスクリプトー ム解析は遺伝子発現(gene expression) プロフィール、プロテオーム解析は遺伝 子産物である蛋白質の機能、プロテオー ムレベルでの発現変化、機能的ネットワ 一ク解析等遺伝子機能に関する研究が主 要なものである(gene function)。薬理 ゲノミクスは、これら三種類のレベルに おける包括的解析により新規創薬ターゲ ツトを決定しようとする新しい研究戦略 である。言うまでもなく、これら三種類 のレベルにおける包括的解析は相補的で あり、技術レベルや現状における成果に 濃淡はあるが、最終的には総合的に解析 することが必要不可欠である。以下にそ れぞれにいて解説する。

\section{2. 遺伝子多型とゲノム創薬科学}

ヒトゲノムプロジェクトの新しい目標は、 遺伝子変異解析であり、特に一塩基多型 (SNPs)解析に関心が集中している。SNPs は、遺伝子多型の最も一般的なものであ り、約 500 塩基対に 1 回出現し、環境や 治療に対する応答の個人差における根源 的基盤とされている。すなわち、SNPs
解析は、癌、糖尿病、循環器疾患、アレ ルギ一疾患、神経疾患などの多因子疾患 に関連した遺伝子同定に役立つことが期 待されている。さらに、この遺伝子多型 は薬効予測(responder, nonreponder)を可能 にすることも期待されている。現時点で は、SNPs 解析と疾患感受性や薬物応答 性に関する研究が開始されたばかりであ るが、今後ゲノム創薬科学における役割 や重要性は計り知れないものがある。一 方、薬物代謝酵素の遺伝子多型と薬物代 謝の関連は、よく研究されており、すで に実用の段階にある。今後さらに、薬物 代謝酵素の遺伝子多型や遺伝子発現プロ フィールのマイクロアレイ法等によるハ イスループット解析が更に普及すること が予測される。

\section{3. 遺伝子発現プロフィール解析と ゲノム創薬科学}

ハイスループットの包括的遺伝子発現プ ロフィール解 (comprehensive transcript expression analysis)は、現時点における薬 理ゲノミクスの中心的アプローチの一つ になっている。その主な理由は技術的基 盤の最近の急激な発展にあると思われる

(表)。すなわち、現在少なくとも三種 類の方法が活用され成果をあげており、 かつその技術革新はまだ留まるところを 知らない。具体的には（1）cDNA のラ ンダムシークエンシング、(2) mRNA デ イスプレイ、（3）ディファレンシャルハ イブリダイゼーションなどがあり、世界 中で活用されている。

そこで現在我々は、この中で DD, FDD, 高 密度 cDNA フィルター、cDNA マイクロ アレイなどを使用してハイスループット 遺伝子発現プロフィール解析により新規 薬物標的分子の探索研究を実施している。 すなわち主に病態時に発現が変動する生 体防御遺伝子や治療遺伝子（新規創薬夕 一ゲット)に焦点を当て解析している(図 
2)。ここで、一つの事実について注意を 喚起したい。それは、現在までの創薬に おいても、薬物標的分子は必ずしも多因 子疾患における疾患遺伝子（産物）では ない事実である。現在の多くの多因子疾 患の薬物標的分子は疾患遺伝子（産物） であることを証明することが困難である。 そこで、我々は新規薬物標的分子の探索 研究における作業仮説として治療遺伝子 ( Therapeutic Genes)を提唱している*。 すなわち、新規創薬ターゲットの探索研 究において、多因子疾患での多数の疾患 遺伝子の探索研究に終始しないで、疾患 遺伝子ではなくとも新規薬物標的分子に なり得ることを仮定して、治療遺伝子探 索研究を実施している。具体的には、治 療薬により病態改善が認められる場合、 病態形成に関与しなくても治癒過程に関 与するものを治療遺伝子候補とする。あ るいは、病態形成に対して拮抗的作用が 明らかな遺伝子（産物）も治療遺伝子候 補リストに加えている(図 2)。その理 由は、現時点では多因子疾患の SNPs 解
表 包括的遺伝子発現プロフィール解析

(1)c DNAのランダムシークエンシング

EST; expressed sequence tag, ボディマップ、

SAGE; serial an aly sis of ge ne expressionなど

(2)m RNAディスプレイ

DD; d ifferntial display,

FDD; fluor escent differential display,

RAP-PCR; RNA a rbitraly primed PCR, Molecular Indexing, GEF; gen e expression fingerprin ting, AFLP; a mplified fragment length polymorphism など

(3)ディファレンシャルハイブリダイ ゼーション

cDNA高密度フィルター、 cDNAマイクロアレイ、 オリゴマイクロチップなど
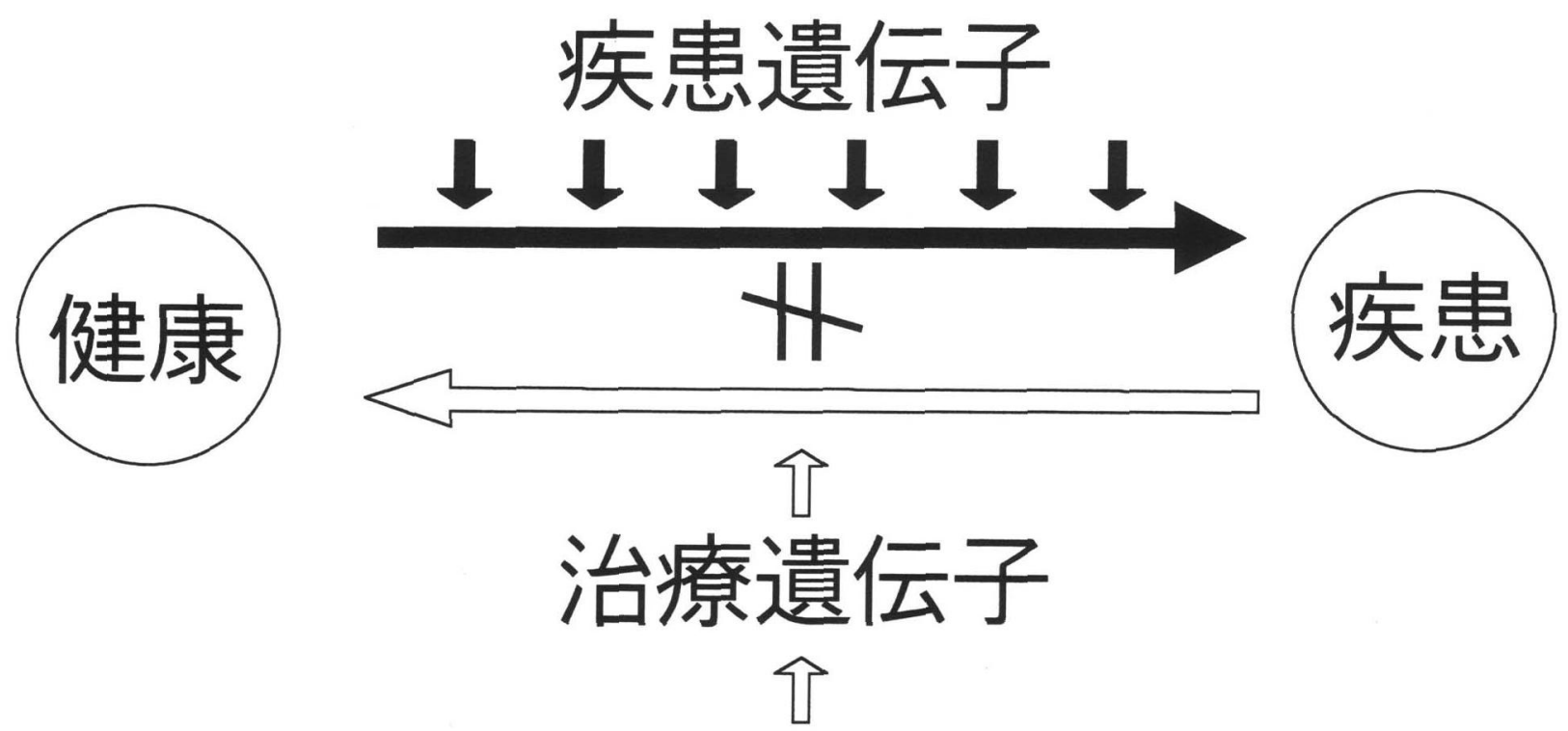

\section{治療薬}

図 2.治療遺伝子は必ずしも疾患遺伝子ではない。 
析や病態解明がまだ不充分であり、疾患 関連遺伝子群は病態マーカーにはなって も、必ずしも治療遺伝子(新規薬物標的 分子）と同一ではないことである（図 2)。 もちろん、病態解析の重要性を否定する ものでは無いが、それだけでは不十分で あり当初より治療遺伝子（新規薬物標的 分子）に対する戦略的探索研究が必要で あると思われる。すなわち、病態解析に おいては発症に拮抗作用の有る遺伝子群 や不完全ながら治療効果の明らかな治療 薬により発現変動する遺伝子群に注目し、 最終的に治療遺伝子（新規薬物標的分 子）を決定する創薬アルゴリスムの構築 を試みている*。

具体的には、自家血の大槽内注入による ラット脳血管攣縮モデルを作製した。そ の結果、脸血管攣縮に明らかに相関して 発現が誘導されるへムオキシゲナーゼ 1(heme oxygenase-1,HO-1)遺伝子に注目し た。そこで、このクモ膜下出血後の HO1 遺伝子発現誘導の治療学的意義につい て解析した。すなわち、アンチセンス HO-1 オリゴデオキシヌクレオチド $(\mathrm{ODN})$ により、HO-1 遺伝子発現を抑制 し、脳血管攣縮への影響を検討した。そ の結果、アンチセンス HO-1 ODN によ り HO-1 遺伝子発現を抑制すると、脳血 管攣縮は増悪することが明かとなった。
そこで、脸血管攣縮における HO-1 遺伝 子発現誘導は、内因性の抗脳血管攣縮因 子であり、新しい創薬ターゲット(治療 遺伝子)の可能性が示唆された*。さらに、 ラットの虚血や低酸素病態における包括 的遺伝子発現プロフィール解析と薬理学 研究から新しい治療遺伝子としての S100Cを見い出した。

今後さらに遺伝子発現プロフィール解析 が、マイクロアレイ法等によりハイスル 一プット化されることにより、体系的遺 伝子発現データベースの構築が可能にな り、創薬への貢献は大きくなると思われ る。また、毒科学の新しい研究戦略とし ても注目されており、今後の発展が期待 される。

さらに、ゲノムスケールでの薬物による 機能変化を解析するためには、薬理プロ テオミクスの確立が近い将来不可欠とな る。いずれにしても、ゲノム、トランス クリプトーム、プロテオームにおける薬 理学的解析は、これからの創薬科学にお ける重要な研究戦略であると思われる**。

*J.clin. Invest.104(1)59-66

**21 世紀の創薬科学、共立出版、

[Abstract] Gene sequensing and gene expression are of particular significance in pharmacogenomics. Sequencing is used to locate polymorphisms, and monitoring of gene expression can provide clue about the genomic response to disease and treatment. Then, we used gene expression profile analysis to identify therapeutic target genes by studying change of gene expression in animal models of oxidative stress and hypoxia. oxidative stress and hypoxia are important in the pathogenesis of various diseases. We found novel drug target candidates in oxidative stress and hypoxia through this pharmacogenomic strategy. our results suggest that the pharmacogenomics have the potential for strategy to define novel drug targets in various diseases. 